\title{
The Problem of Evil IN THE QUR'AN, TRADITIONS AND INTELLECT
}

\author{
Morteza Agha-Mohammadi \\ "Urwat al-Wusqa" Research Center, \\ Al-Mustafa International University, Qom, I. R. Iran
}

\begin{abstract}
The problem of evil as one of the strongest arguments against the existence of God is discussed a lot by theologians of different religions. The purpose of this article is to study the philosophies and wisdom behind the presence of evils in man's life by appealing to the Qur'an, the traditions of the Prophet Mohammad and his household as well as to intellectual arguments, as three main sources of Shia Islam. By extending the realm of life from the material world to the life after death, this study puts man in a more extensive paradigm and intends to show that for a believer, the existence of evils does not contradict having faith in a just, kind, omnipotent and omniscient God. One of the important points which are given attention in this article is a differentiation between the responsibility of man and that of God. This point clarifies how in many cases the roles of the claimant and of the defendant are confused.
\end{abstract}

Keywords: Problem of evil, philosophy of evils, Qur'an, Traditions, Intellect, existence of God

\section{Introduction}

The problem of evil is among the most important and contentious theological debates in almost all religions. The existence of evils in the universe is one of the strongest arguments against the existence of God. How can one believe in a creator who is wise, able and kind, while all these problems, sufferings, grief, bitterness, failure, murder, crimes, and all sorts of oppression have enveloped human life?! If the occurrence of these incidents is frought 
with the assumption of the existence of a God and a creator, then either it is due to his weakness in confronting these events or because of a lack of knowledge to deal with them or, perhaps, it is owing to God being merciless and a sadist who takes pleasure in the problems of his creatures, or at least he is indifferent towards them. Therefore, these disasters and evils make some people deny the existence of God, or at least some of His attributes such as justice, omniscience, and omnipotence. What comes in this article may not satisfy a non-believer, but the point is to show that a faithful man does not find the hardships and so-called evils to contradict his faith. On the other hand, understanding these various aspects and possible dimensions, with regard to a tragic event, makes believers avoid superficial judgments about these matters. When somebody encounters a disaster or an unhappy incident, perhaps majority of religious people relate it to sin, in which the amount of misery is measured by the size of the individual's sin. In this conventional view, hardships and miseries are viewed as revenges and punishments befalling man for his error.

Hence, theologians from various religions have tried to answer this criticism, and in this regard, numerous articles and books have been written, among which John Hick and Alvin Plantinga's works written from a Christian perspective and the books authored by Sayed Muhammad Hussain Tabatabai and Morteza Motahhari from Shia scholars are of great importance. John Hick uses the soul making approach, Alvin Plantinga applies the free will approach to answer to the problem of evil, while Tabatabai and Motahhari refer to the free will and the non-existential nature of evils to solve this problem. The present article is a humble attempt to use the verses of the Qur'an and the traditions of the Prophet Mohammad and his household, as narrated in Shia books, as well as some of rational arguments to examine the many and complex aspects of hardships in man's life. There are usually six or seven points to be mentioned by the Shia scholars as the reasons and wisdom behind the evils. Thus, our findings go beyond those studies.

\section{Possibility of Connection Between the Events of This World with Non-Material Causes}

According to materialists, natural disasters such as floods, earthquakes, contagious diseases, wars and other problems, are all caused by natural forces. Whenever and wherever these causes are available, their effects will also come by, regardless of whether the residents are righteous people or evildoers. Therefore, it is meaningless to associate these events with good or bad behavior of the people. Based on this viewpoint, attributing natural happenings to good/bad behavior is a religious hypothesis which does not 
correspond to reality. In response to this misunderstanding, Allamah Tabatabai says:

These people think that the Qur'an and the faithful associate bitter and sweet happenings with people's behavior in order to negate the causality of natural causes, but it is not the case and the belief in the influence of actions is taken for granted. The believers do not want to deny causality. They consider a higher cause in line with natural causes that are not parallel to one another. They are longitudinal causes the nearest of which to events are natural causes, and what activates these causes is divine mercy or divine wrath and what brings about divine mercy or wrath are good or bad deeds. It is similar to writing a letter which can be attributed either to the tip of the pen, or to the pen itself, or to the hand of the writer or the writer him/herself (Tabatabai 1995: II/277).

Some events happen as a result of man's good or bad deeds and some are natural impacts of man's actions; for example, bad behavior toward one's parents will lead to a decrease in one's earnings even if the person struggles a lot to earn money. But sometimes the person's earnings decrease owing to one being inactive and that is a natural consequence of one's behavior. The worst state for such a person is to have his earnings increased as a consequence of such a sin that is called the state of Istidraj, which will be discussed soon. All of these cases must be studied in detail.

\section{Purposeful Creation}

The wisdom and consistency in creation should be defined based on the purpose of the creation. About the purposefulness of the creation, God has said in the Qur'an:

Did you suppose that We created you aimlessly, and that you will not be brought back to Us? (Qur'an 23: 16)

From the viewpoint of religion, this world is a pathway to final perfection in the Hereafter and the joys of this world are not a purpose in themselves. Therefore, the events in this world should not be analyzed only with a view to the worldly life, but they should be evaluated in the context of perpetual life beginning in this world and continuing in the Hereafter. 


\section{The Concept of Qada and Qadar}

Literally, Qadar means measurement and Qada means fixed and unchangeable affair (Sobhani 1998: 103). As Imam Ridha said: "Qadar is to determine limits such as life and death, and Qada is to make it certain (Kulayni 2008: I/158). For instance, the special shape of an apple, with a specific weight and color. Whatever forms the external reality of an apple is considered its Qadar. And since God has knowledge of the shape, color and the external reality of the apple, it is called the knowledge-based Qadar, and since God has created the apple with those specifications and external reality, it is called the action-based Qadar. Therefore, the belief in Qadar equals the belief in God's creation and His eternal knowledge of creatures. But Qada technically means the certainty of something and its actualization when its complete cause is realized. When there is an apple tree, and its natural factors such as water, soil, sunlight and appropriate weather and other required factors exist and work together, thereupon the tree will definitely flourish. This is the divine Qada.

Qada and Qadar have the same meaning in the events of life. Suppose that a moving car hits a person. If the car was moving at a speed of $10 \mathrm{~km} / \mathrm{h}$, it may not hurt the person. If the speed is $20 \mathrm{~km} / \mathrm{h}$, it may cause bruises. If it is $60 \mathrm{~km} / \mathrm{h}$, it may break a bone and if it is $100 \mathrm{~km} / \mathrm{h}$, the person may die. In all these cases, it will differ depending on whether the car hits the leg or the head or other parts of the body, each leading to a different type of damage. All these are the Qadar of the accident. So if a person is standing on a specific part of the street at a specific moment and place, he will definitely have an accident. However, if the person arrives at that spot one second earlier or one second later, the accident will not happen. This is also a divine Qadar in an accident. Thus the divine Qadar does not imply that God has willed this person to die or become wounded. However, sometimes divine will is for an accident to occur in which case it is called the divine Qada or predestination. Thus, in any event God's measurement (Qadar) exists, but sometimes it turns to be determination (Qada).

\section{The Philosophy of Evil in the Qur'an, Traditions and Intellect}

In this introduction we deal with the probable wisdom/philosophy of sweet and bitter happenings in one's life. It should be noted that no-one can claim with certainty that something has happened for such-and-such reason, except if one is granted divine knowledge, as in the case of prophet Yusuf (Joseph), in which case the Qur'an says: "That is how your Lord will choose you, and teach you the interpretation of dreams, and complete 
His blessing upon you" (Quran 12: 6). Based on this verse, God had granted ta'wil al-ahadith to Yusuf. Ta'wil means to return things to their origins. Ahadith is the plural form of hadith meaning event or incident, so ta'wil al-ahadith means to return every event to its origin to see for what reason it has occurred.

\subsection{Testing}

The Qur'an reads: "Indeed We have made whatever is on the earth an adornment for it that We may test them [to see] which of them is best in conduct" (Qur'an 18: 7).

Here adornment is any beautiful thing that when attached to something will add to it beauty and attract everyone. It is divine will for humans to achieve eternal perfection and happiness through faith and deeds upon the truth. Therefore, God has helped man settle on earth for a while and has created the love of what is on earth in his heart so that he becomes attracted to wealth, children and power. That is to test each person to differentiate between the saved ones and others (Tabatabai 1995: XIII/333).

We will surely test you until We ascertain those of you who wage jihad and those who are steadfast, and We shall appraise your record

(Quran 47:31).

Therefore, this world is a place characterized by hardships, vicissitudes and difficulties and if a person looks for welfare and comfort, he will encounter difficulties; even when everything is going smoothly, he fears losing the bounties and becomes upset. But if one sees this world as a farm to plant the seeds of perfection and move to another world, he will consider the hardships as divine gifts because he will receive a lot of rewards for tolerating those hardships, as will be discussed.

\subsection{Major Tests}

Do the people suppose that they will be let off because they say: 'We have faith,' and they will not be tested? Certainly We tested those who were before them. So Allah shall surely ascertain those who are truthful, and He shall surely ascertain the liars (Qur'an 29: 2-3).

Ibn Abbas has said, "Among those whom this verse has been revealed about is the prophet Abraham and a group of people who had accepted his call to believe in God, and then they suffered hardships for the sake of God 
such that the pagans sawed their bodies in halves". Another exegete has said that: "This verse is about the children of Israel who were tortured brutally by Pharaoh out of arrogance" (Al-Tabarsi 1981: XIX/9). In another commentary work, it is said that this verse is about Ammar ibn Yasir and other people who suffered hardships in the way of Islam (Al-Muqniyah 2004: 520). After reciting the above-mentioned verse, Imam Ali quoted the Prophet Muhammad: "Any community of the followers of a prophet will be tested in a major test by their prophet to distinguish the honest from the liar" (Sharif Lahiji 1994: III/505).

According to Allamah Tabatabai, this testing is a continuous divine practice which has occurred in previous nations as well: "Do they not see that they are tried once or twice every year? Yet they neither repent, nor do they take admonition" (Qur'an 9: 126).

The term al-Fitna that is used by its derivatives in these two verses, literally refers to the heating gold to distinguish pure gold from the contaminated one (Qurashi Banae 1991: V/147). Here, al-Fitna refers to being tested by different types of hardships and jihad along with the Holy Prophet (Fayz Kashani 1994: II/391). Fitna here means disorder in the normal life caused by contagious diseases, wars and conflicts and continuous fear and insecurity. Therefore, to be afflicted with Fitna means that God sends down losses and hardships on them, and since it is against the normal flow of life, God wants to free them from ignorance (Ibn Ashur 1999: X/234). According to this verse, Fitna occurs once or twice a year. It targets one's faith to move one towards disbelief (Bayzawi 1997: III/103). A Fitna which happens once or twice a year is famine and diseases. However, they are not freed and do not repent after these hardships (Suyuti \& Mahalli 1995: 210).

It can be concluded by studying different interpretations that Fitna is a type of event which is intended to awaken these groups. It is deciphered from the last verse that it is different from general tests which people face in their lives. Fitna is a test but since it is an important issue which happens once or twice a year, it is different from tests which are always there; whether a person performs his prayers in its due time or postpones it, is a test but not Fitna. Fitna is a great test such as a severe disease for oneself or one's immediate family members, severe financial loss, important political or social responsibilities such as jihad and the like can be considered as instances of Fitna which have the potential to deviate an individual. Fitna is a difficult test which comes to destroy the faith and it seems that many people fail this type of test. That is why the verse goes on saying "Yet they neither repent"; it means that Fitna is such that people are susceptible to failure but they should repent immediately after they fail and return to their God instead of remaining in that state. Another point is that Fitna causes man to incline to- 
ward deviation and to start having doubts. Therefore, one should safeguard his faith through prayer and repentance.

Know that your possessions and children are only a test (fitna), and that Allah - with Him is a great reward. (Quran 8: 28)

A test with excessive wealth and children would be difficult and it is feared that one may fail this great test. Fitna in respect of children comes sometimes in the form of a loss in one's child or children as well as in the sufferings caused as a result of their illness or death. Sometimes, it occurs when one's children have expectations which may lead them to committing sins. A father who commits a forbidden act to meet the demands of his wife and children has failed the Fitna.

Fitna is not always in the form of punishment. Sometimes it is in the form of bounties and pleasures, in which case it is also called istidraj (Divine beguilement/entrapment). It was mentioned earlier that the goal of Fitna is to deviate a person. From this point of view, istidraj is also an instance of Fitna. There is a hadith which says:

Istidraj means that man is granted plentiful bounties but he is not grateful (Ibn Shu'ba Harrani 1983: 246).

He has a wrong perception of the situation thinking he is a good servant of God because he has been granted profuse bounties. Sometimes he is aware of his evil and wrong actions. In this case, well-being and a life without pain has deviated him to the extent that he thinks there is no God otherwise, He would blame and reprimand him for the vices and wrong actions. The Qur'an narrates the story of Korah (28: 76-79), who got arrogant and forgot God after being very rich, as a person who underwent Istidraj.

\subsection{Hardships as Atonement for Sins}

The Prophet Muhammad said: "There are some sins to which no prayers or alms can be their atonement". He was asked: "What is the atonement for them?" He said: "Sadness in finding one's daily bread is the atonement for those major sins" (Rāwandi 1986: 119). It can be inferred from this hadith that prayers and alms themselves are atonement for a believer's sins as it is mentioned in this verse: "Maintain the prayer at the two ends of the day, and during the early hours of the night. Indeed, good deeds efface misdeeds. That is an admonition for the mindful" (Qur'an 11: 114). 
And if these good deeds cannot atone for the sins, some type of sorrow will happen in life which will atone for that sin. That is why Imam al-Baqir ibn Muhammad introduces the hardships as divine gifts for the believers: "God will constantly send hardships to a believer just as the believer brings souvenirs for his family every time he goes on a trip..." (Qur'an 44: 38).

\subsection{Punishment}

Sometimes the hardships and problems in life are owing to man's bad actions and they respresent punishments. Punishments are for two groups of people:

\subsubsection{Punishment for Believers}

Punishment for believers in this world is sometimes referred to as ' $u q u$ bat (punishment) and sometimes as niqmat (chastisement).

"O God! Do not discipline me with your punishment!"

'Uqubat is meant for purification and removal of the impurities of the believers. When a believer commits a sin but does not perform good actions to make up for it, God will afflict him with hardships and difficulties to atone for his sins. In a prayer that he taught Kumayl ibn Ziyad, Imam Ali ibn Abi Talib addresses God as such:

"O Allah, forgive me for those sins which draw down chastisements!"

According to this supplication by Imam Ali, some sins result in niqmat. Niqmat refers to a punishment which is accompanied by reprimand, hate, and blame (Mustafawi 1989: XII/227). This kind of punishment is worse than mere punishment. Sometimes a father punishes his child, but even the child knows that the father loves him. But sometimes punishment is in such a way that it is as if the punisher hates the punished. When the punisher is a great person and is loved by the punished, the mental punishment will become more hurting and painful than the physical punishment. It is narrated from Imam Ali that: "Allah, the Glorified, has laid down... Punishment for committing sins against Him in order to save men from His chastisement (Niqmat)" (Sharif al-Razi 1993: 539).

So God punishes His servant so as to awaken him and prevent him from becoming a subject of divine wrath. 


\subsubsection{Punishment of the non-believers}

About the people of Noah we read in the Qur'an that:

And Noah's people, We drowned them when they impugned the apostles. (Qur'an 25: 37-40)

Elsewhere, we read about the punishment of Pharaoh's people because of their sins: "As in the case of Pharaoh's clan and those who were before them, who denied Our signs. So Allah seized them for their sins, and Allah is severe in retribution" (Qur'an 3: 11). The sins of the people of Thamud also resulted in their affliction with divine punishment: "We unleashed upon them a rain of stones" (Qur'an 54: 34).

According to the verses, this punishment has some signs:

A. The punished people die without having a chance to ask for forgiveness;

B. This punishment comes at the time of their corruption and arrogance;

C. The punishment comes when the majority of people are corrupt and arrogant;

God has warned them in advance, but they mocked or threatened in return. They said: "O Noah, you have disputed with us already, and you have disputed with us exceedingly. Now bring us what you threaten us with, should you be truthful" (Qur'an 11:32).

D. The believers were fed up with their oppression and did not have the power to confront them.

\subsection{Self-Created Tribulation}

"Corruption has appeared in land and sea because of the doings of the people's hands, that He may make them taste something of what they have done, so that they may come back" (Qur'an 30: 41). Some disasters happen as a result of man's wrong plans or inefficiency and absenteeism. Those who have not paid enough attention to the upbringing of their children, when they become undisciplined and demonstrate misconduct, parents will start complaining that they have done nothing wrong and they wonder why God granted them those children. When someone drives while being drunk or sleepy and causes an accident, his family members start complaining about 
the calamity that has struck them and wondering why such a thing had to happen to their child. Those who build substandard houses which are not strong enough and when there is an earthquake, they expect God to save them. Usually, when an earthquake takes place, people start passing judgment and saying that those people have been the target of divine wrath and the next question that normally follows is: "Why do only we become the target of divine wrath? Why are most of non-Muslim nations not afflicted with disasters and divine wrath? Why do the Europeans not have earthquakes?"

The answer to these questions lies in simply thinking about why earthquakes shake Japan at high degrees on the Richter scale but not even a single person dies. Their earthquake-resistant buildings are built according to the engineering standards and it is for the same reason that there are few casualties and the death toll is very low, but does it mean they have stopped divine wrath? In fact, it means that they have taken the appropriate action, one that is based on rationality and natural laws. Tectonic plates move and sometimes they exert pressure on each other and shake the earth which is suitable and contributes to the continuation of life on earth; however, when we build weak houses on faults (planar fractures on earth's crust) which will collapse with a small earthquake, here God is not responsible.

Clear is Allah of whatever they allege [about Him] (Quran 37: 159).

Disasters such as earthquakes have made man find a solution and make extraordinary accomplishments in architecture and housing. With this approach, disasters turn into opportunities. In fact, these events must not always be interpreted as divine punishments. However, it does not mean that disasters such as earthquakes are never a divine punishment for some people.

\subsection{Other People's Deeds}

Sometimes an individual or a society is afflicted with tribulation as a result of the actions of others, but naive people still consider God responsible for that. For example, some countries in the third world suffer from poverty and many people lose their lives each year. But it is not God's will. It is partially due to colonization by Imperial powers in recent centuries and exploitation of their resources by these powers that keep them in constant poverty. Now instead of holding the oppressor countries responsible for it, they blame God. On the other hand, a part of the problems in these poor countries is due to their own ignorance and incompetence. Those countries which have decided to struggle have managed to achieve independence and attain economic development. South Africa is an example of those countries 
which at least have experienced outstanding economic growth and it has become a role model for other African countries.

There was a famous woman who had spent all her life giving humanitarian aid to people, especially to Africans. She once related how at the end of her life she said she no longer believed in God. After witnessing so much poverty and fatalities, she had concluded that there was no God, otherwise He would have done something. She had not realized that it was a divine plan for humans to move and shape their destiny. The cause of poverty is colonization and the people's lack of action aimed towards improving their situation. When people do not do anything to change their lives, God will not change them, as the Qur'an reads:

Verily never will Allah change the condition of a people until they change what is in themselves (13:11).

Moreover, what should God do if He wants to do something? Should he fill their kitchen and refrigerators with food? Or tell the angels to take food to them? These are against the normal flow of life and will destroy the belief in the unseen and will disrupt the order and everyone will stop working. The only rational option is that people themselves should strive and those who can help, should help. God will hold people responsible as to why they did not help their friends or neighbors when they could. Suppose there is a careless driver who drives at a speed higher than the speed limit and hits and kills a person. Here it is unfair to forget about the driver and complain to God because of the man's death.

Evils are non-existent elements which cannot be attributed to God because whatever is attributed to God is existent. So the good things that are existent are attributed to God. The sun shines on the earth and the sunlight causes it to become bright, but darkness is not because of the sun since only light comes from the sun. It is the spherical shape of the earth which makes it unable to receive the light on all its parts, while it does not make any difference for the sun because it keeps shining anyway. Similarly, God constantly sends His grace, but it depends on the capacity and nature of the creature to benefit from it. That is why "Whatever good befalls you is from Allah; and whatever ill befalls you is from yourself” (Qur'an 4: 79).

\section{7 \& 4.8. Conditional and Absolute Ajal (Time of Death)}

Some of you die earlier and some of you complete a specified term (Ajalan Musamma) (Qur'an 40: 67). 
Ajal literally means the end of the time of something (Raghib Isfahani 1992: 11). The first case of Ajal in the verse (Some of you die earlier) which is indefinite refers to conditional Ajal or indefinite one, and the second case of Ajal is the fixed length of life or definite Ajal (Ajalan Musamma). This is the fixed death that will not change. God has said: "When their time comes, they shall not defer it by a single hour nor shall they prolong it" (Tabatabai 1995: VII/8).

The indefinite Ajal may not happen in time because its condition has not been met, but the fixed and appointed Ajal will definitely happen and cannot be stopped (Qur'an 10: 49). It is similar to a building that will be standing for 100 years (fixed Ajal) on the condition that there is no earthquake in these 100 years, but if an earthquake happens, it is conditional Ajal. A specific person may live up to 90 years on the condition that the person does not have cancer or a deadly accident. So if it is preordained for someone to die at the age of 90 , and he reaches that moment, the person will die without delay. However, this person has a conditional indefinite Ajal that is pending; for example, if he takes in a lot of fat and does not have physical exercise, he will have a stroke at the age of 40 . Or he is definitely going to die at the age of 30 if he commits a sin or does not pay alms or does not do good deeds or has cut off the ties with his close relatives. However, if he pays alms or maintain relations with his close relatives or prays, this conditional Ajal will be cancelled and postponed. Imam al-Sadiq has said:

Praying cancels disaster even if it has been definitely determined (Kulayni 2008: IV/304).

Noah would tell his people this: "Worship Allah and be wary of Him, and obey me, that He may forgive you some of your sins and respite you until a specified time. Indeed, when Allah's [appointed] time comes, it cannot be deferred, if you know" (Qur'an 71: 4).

A few points can be inferred from this verse:

First, worshipping God and asking for divine forgiveness will bring bounties and forgiveness of the sins. Second, asking for divine forgiveness and obeying God will delay the death up to the fixed and specified Ajal. And if a person does not obey God and does not ask for divine forgiveness either, his death will not be delayed. "He calls you to forgive you a part of your sins, and grants you respite until a specified time" (Qur'an 14: 10). This verse stipulates that through this call, God wants to forgive the sins and delay one's death to the absolute Ajal; it means that in case of disobedience, forgiveness and delay in death will not take place and death will come earlier. As it was already mentioned, it does not mean that in all cases a good person lives 
longer and bad people live short lives, since there might be other wisdoms to entail a short life for the former and a long life span for the latter.

\subsection{Inayat (Better Replacement)}

In the story of Moses and Khidr when they were on a trip together, Khidr killed a child. Moses complained and said: "You have certainly done a dire thing!" Khidr answered: "As for the boy, his parents were faithful [persons], and We feared he would overwhelm them with rebellion and unfaith" (Qur'an 18: 80). Khidr said: "So We desired that their Lord should give them in exchange one better than him in respect of purity and closer in mercy" (18: 81). ${ }^{1}$ Imam al-Sadiq said: "God granted parents of that child a girl from whom seventy prophets were born" (Nuri 1987: XV/117). Here the child is only an example. Sometimes it is wealth or power that corrupts man, so God deprives one whom He loves of these things to grant him better things. In a letter from the Commander of Faithful, Ali ibn Abi Talib to his son Hasan it reads: "Delay in acceptance of prayer should not disappoint you because the grant of prayer is according to the measure of (your) intention. Sometimes acceptance (of prayer) is delayed with the view of its being a source of a greater reward to the asker and of better gifts to the expectant. Sometimes you ask for a thing but it is not given to you, and a better thing is given to you later" (Sharif al-Razi 1993: 399).

\subsection{What Just Appears to Be Evil}

Yet it may be that you dislike something while it is good for you, and that it may be that you love something while it is bad for you and God knows what you knew not (Qur'an 2: 216).

Sometimes a person suffers from a disease which protects him from a greater problem or evil. An illness may force someone to cancel a journey he had decided to take. Had he embarked on a journey, he would most likely have gotten in an accident which would lead to his death. This tiny evil (falling ill) that appears to be unpleasant is actually a great blessing for the person. Thus deprivations can be a way for protection against greater evils or problems. One of the eminent Iranian scholars narrated a story of his childhood, saying they used to live in the outskirts of the city of Tehran. They usually went playing with their neighbors in the compound outside the house that was surrounded by farms and gardens. Once a friend of his found

1 It must be noted that according to Sharia one cannot punish a person before committing any crime. Thus, what this man did was an exception. 
some dove eggs. However much they insisted that he should give them a few, he refused. They were upset because of what he did. Days passed by, and then they heard a lot of noise coming from the alley. They ran towards that house and they saw everyone was running towards the said friend's house. "When I got there, I saw my friend's house was full of snakes. I suddenly understood that these were snake's eggs, not those of a dove. The snakes had been hatched and they had scattered throughout the house. Now I felt very happy that I avoided what I had been crying about" (Agha-Mohammadi 2016: 85). Some issues appear to be bad, annoying and depriving, but they are imbued with mercy and goodness.

\subsection{Relative Judgment}

We happen to consider things as evil just because they are not in line with our interest, but they can be essentially different from what they appear to be. We treat ourselves as the axis of the world and judge everything based on our own interest. Therefore, whatever is not in our advantage we consider it somehow bad or wrong. With this approach and interpretation of things, catastrophes like earthquakes, floods or even snakebites are evil. On the other hand, the snake bite is a means for its protection as well as to hunt its prey, and without it a snake cannot survive. With this capability, animals like rats are hunted and eaten by snakes and the balance is established in the life cycle. Besides, if our knowledge is advanced enough, we can use the same poison to make medicines for different diseases. When it rains heavily in one area, we do not have enough understanding to perceive the outcomes of it in its large scale, so we consider it an evil as soon as it hurts us.

\subsection{Difficulties and Problems Are the Spice of Life}

Ups and downs, hardships and joy, find meaning with respect to each other. If man does not face difficulties, life will be monotonous and will lose its taste. There are rich people who live luxurious lives, but feel depression for finding it so boring (Ibid.: 112). There are even cases of people committing suicide without having any notable problem in the life. He who does not experience poverty cannot enjoy the pleasure of affluence. One who does not fall sick will not realize the importance of his health.

\subsection{Awakening a Human Being}

We seized them with stress and distress so that they may entrust

(Quran 6: 42). 
Sometimes hardships and difficulties are meant to awaken someone from negligence and heedlessness as well as to lead him to the right path. When someone is sad and oppressed, it is likely that this situation will decrease his arrogance. While in happiness, it is possible for him to be proud and arrogant. "Indeed man becomes rebellious when he considers himself without need” (Qur'an 96: 6-7).

The Qur'an describes Korah so rich that some strong men were needed to carry the keys of his treasury stores. Upon becoming wealthy and rich, he was ungrateful to God and forgot all the poor people since he just wanted to accumulate more wealth (28: 77). Thus, if life does not show its ugly face and all life is joyful, man is likely to think that the pleasures he has are abundant and everlasting. Naturally, he invokes and prays to God less often and forgets his eternal abode.

\subsection{Great Rewards}

Say (Allah declares): "O My servants who have faith! Be wary of your Lord. For those who do good in this world there will be a good reward, and Allah's earth is vast. Indeed the patient will be paid in full their reward without any reckoning" (Qur'an 39: 10).

When Imam Hussein ibn Ali and his people faced the army of their enemy, Imam told his companions that the allegiance they had made to him was removed and they could go back to their families. He said the same thing to the members of his family by saying that the enemies were looking for him only, so they could leave. Some of his companions left him but his family members and those closest to him said: "We cannot leave you until what happens to you also happens to us, and your tragedy will be our tragedy and we shall share your grief". Then He said to them: "If you are prepared for what I have prepared myself for, then know that indeed Allah donates to his servants who are patient with difficulties beautiful and respectful abode" (Imam al-Askari 1988: 218).

\subsection{The Perfection of Man in Challenging Situations}

From a mystical perspective, there are different benefits in hardships and one of them is that it prepares man's heart for its perfection. This effect shows itself in different ways. 


\subsubsection{Learning about One’s Weak Points}

Difficult situations in life show a person his weak points. It is possible for people in normal situations to feel that they are very good and that they do not have any weaknesses and deficiencies, but when they get tested by calamities, it will be seen that many people fail. The calamities act as a reminder to show that one's faith is not strong enough to keep the person safe and steadfast till the end of the journey of perfection.

\subsubsection{Elimination of Attachments}

Calamities disengage man's heart from worldly attachments so that the soul gets free. "No adviser could cut me off from my attachments like what hardships do. Observing the needs, changes, deprivations and death of the beloved ones has taught me not to engage my mind with anything or anyone other than you. ${ }^{1}$ How can I put my hope and love in those who cannot protect themselves?" (Safaei Hāeri 2013b: II/373)

\subsubsection{Increase in Caliber}

From the mystical viewpoint, the calamities man encounters render him able to enhance his caliber. The Qur'an says: "And I breathed into him of My spirit" (Qur'an 38: 72).

This verse shows the limitlessness of the soul gifted to man. The term "my soul" mentioned in the verse refers to the eternal God-gifted soul that can bear limitless capacity. As it was already said, the hardships detach the heart from the worldly attachments and this detachment makes the heart develop in its capacity. A mystic learns to be happy in the heat of the difficulties.

\subsubsection{Having a Broken Heart}

One of the effects of hardship is leaving man with a broken heart. According to the mystical understanding, when the heart breaks God enters it. As already mentioned, when man is in a well-off state, he is likely to get arrogant and misbehave, but when the hopes are gone and man feels empty-handed, it is the moment he truly calls God. "Blessed are those whose

1 Not loving anything and anyone except God does not mean to be indifferent toward others, but it means that nothing is adored the way a believer adores God. Otherwise, a person who loves God is a lover of whatever belongs to God. 
hearts are broken for the sake of Allah" (Laithi al-Wāsiti 1997: 313). Normally mystics practice the ascetic codes and go through self-mortification. As a result, they generally tend to get proud of their conducts. This pride in mystical cognition is one of the worst sins (Safaei Hāeri 2013a: 56-55). Bearing this fact in mind, the calamities help one ascend to God and have a humble heart. They make man lose all arrogance and selfishness.

\section{Conclusion}

There are different justifications for the existence of evils and hardships in man's life according to Islamic perspective that keeps harmony between their presence and existence of God and His divine attributes. It should be kept in mind that an event may have different dimensions, for instance, an accident may happen due to the negligence or drowsiness of the driver. The driver is dead, and the death is the result of his own reckless driving or negligence. He has a corrupt and oppressive father who is punished by this calamity. His mother is a decent and pure woman and this tragedy increases her perfection and elevates her status with God. For other relatives, it could be a test, and so on. Therefore, the aspects mentioned above do not include a phenomenon exclusively, so an incident could, from various aspects, have different rulings for different individuals. All or some of the philosophies mentioned in relation to the presence of evils may not appeal to a non-believer, but it is important that a faithful man finds them acceptable and does not consider them a challenge for having faith.

Received: November $2^{\text {nd }}, 2018$.

Accepted: December 6 ${ }^{\text {th }}, 2018$.

\section{References}

The holy Quran

Agha Mohammadi, Morteza (2016), Falsafeye Ebtela'at, Qom, Rasule A'zam publication.

Al-Muqniyah, Muhammad Jawād (2004), Al-Tafsir al-Mubin, Qom, Bonyade Be'that.

Al-Tabarsi, Fazl ibn Hasan (1981), Majma’al-Bayan fi Tafsir al-Qur'an, Tehran, Farhāni.

Bayzawi, Abdullah ibn Omar (1997), Anwār al-Tanzil wa Asrār al-Ta’wil, Beirut, Dāru Ihya al-Torāth al-Arabi.

Fayz Kashani, Muhammad ibn Muhsin (1994), Tafsir al-Sāfi, Tehran, Al-Sadra Publication. 
Ibn Ashur, Muhammad ibn Tāhir (1999), Al-Tahrir wa al-Tanwir, Beirut, Mu'assasa al-Tarih al-Arabi.

Ibn Shu'ba Harrani, Hasan ibn Ali (1983), Tuhaf al-Uqul an Al al-Rasul, Qom, Jame'eye Modarresīn Publication.

Imam al-Askari, Hasan ibn Ali (1988), Tafsir al-Imam al-Askari, Qom, Imam Mahdi Publication.

Kulayni, Muhammad ibn Ya’qub (2008), Al-Kāfi, Qom, Dār Al-Hadith Publication.

Laithi al-Wāsiti, Ali ibn Muhammad (1997), Uyoon al-Hikam wa al-Mawa'edh, Qom, Dār Al-Hadith.

Mustafawi, Hasan (1989), Al-Tahqiq fi Kalimat al-Qur'an al-Karim, Tehran, Ministrey of Culture and Guidance of I. R. Iran.

Nuri, Husain ibn Muhammad Taqi (1987), Mustadrak al-Wasa'il wa Mustanbat al-Masa'il, Qom, Alul-Bayt Institute.

Qurashi Banae, Ali Akbar (1991), Qāmuse Qur'an, Tehran, Dār Al-Kutub Al-Islamiyah.

Raghib Isfahani, Husain ibn Muhammad (1992), Mufradat Alfaz al-Qur'an, Beirut, Dār Al-Shamiyah.

Rāwandi, Qutb al-din (1986), Al-Da’awāt, Qom, Imam Mahdi Publications.

Safaei Haeri, Ali (2013a), Ekhbāt, āqāz Dar nahāyat (The Digital Collection of Ali Safaei's Books), Qom, Noor Institute.

Safaei Haeri, Ali (2013b), Tathir bā Jārie Qor'an, Aqāz Dar Nahāyat (The Digital Collection of Ali Safaei's Books), Qom, Noor Institute.

Sharif al-Razi, Muhammad ibn Husain (1993), Nahj al-Balaqa, Qom, Hijrat Publications.

Sharif Lahiji, Muhammad ibn Ali (1994), Tafsir Sharif Lahiji, Tehran, Dād Publications.

Sobhani, Ja'far (1998), al-Aqida al-Islamiyah ala Zau'i Madrasatu Ahl al-Bayt, Qom, Imam Sādiq Institute's Publication.

Suyuti, Jalāl al-Din; Mahalli, Jalal Al-Din (1995), Tafsir al-Jalālain, Beirut, Institute al-Noor.

Tabatabai, Muhammad Husain (1995), al-Mizan fi Tafsir al-Qur'an, Translated by Muhammad Baqir Musawi Hamedani, Qom, Jame’eye Modarresin. 